\title{
Fire Influences on Atmospheric Composition, Air Quality and Climate
}

\author{
Apostolos Voulgarakis ${ }^{1} \cdot$ Robert D. Field ${ }^{2}$
}

Published online: 24 May 2015

(C) Springer International Publishing AG 2015

\begin{abstract}
Fires impact atmospheric composition through their emissions, which range from long-lived gases to shortlived gases and aerosols. Effects are typically larger in the tropics and boreal regions but can also be substantial in highly populated areas in the northern mid-latitudes. In all regions, fire can impact air quality and health. Similarly, its effect on large-scale atmospheric processes, including regional and global atmospheric chemistry and climate forcing, can be substantial, but this remains largely unexplored. The impacts are primarily realised in the boundary layer and lower free troposphere but can also be noticeable in upper troposphere/lower stratosphere (UT/LS) region, for the most intense fires. In this review, we summarise the recent literature on findings related to fire impact on atmospheric composition, air quality and climate. We explore both observational and modelling approaches and present information on key regions and on the globe as a whole. We also discuss the current and future directions in this area of research, focusing on the major advances in emission estimates, the emerging efforts to include fire as a component in Earth system modelling and the use of modelling to assess health impacts of fire emissions.
\end{abstract}

Keywords Fires · Biomass burning · Carbon monoxide . Ozone $\cdot$ Aerosols $\cdot$ Radiative forcing $\cdot$ Injection heights

This article is part of the Topical Collection on Air Pollution

Apostolos Voulgarakis

a.voulgarakis@imperial.ac.uk

Robert D. Field

rf2426@columbia.edu

1 Department of Physics, The Blackett Laboratory, Imperial College London, London SW7 2AZ, UK

2 Department of Applied Physics and Applied Mathematics, Columbia University, 2880 Broadway, New York, NY 10025, USA

\section{Introduction}

Fire is a central component of the Earth system [1,2]. There are several key linkages between fire, the atmosphere and the biosphere, with implications for climate change, ecosystems, human health and the economy. Forest fire activity is strongly affected by climate change, since temperature, humidity and precipitation can affect the flammability of vegetation [3, 4] and since vegetation itself undergoes changes driven by climate change. Furthermore, fire activity depends on the ignition sources available in a region, which can be natural (lightning) or anthropogenic (accidental or deliberate) [4], with the natural sources potentially influenced by climate change as well.

Fire activity has changed drastically in the past and is expected to change in the future. Specifically, it has been suggested that from the preindustrial to the present day, fire activity increased until 1950 and subsequently decreased due to anthropogenic management [5], while in the future, it will potentially increase due to the climate warming expected [5-7]. At the same time, fire activity shows large interannual variations both on global and on regional scales [8]. The atmosphere is affected strongly by these changes in fire activity [9•] through large amounts of emissions that can affect pollution levels, atmospheric chemistry and climate.

There are both gaseous and aerosol emissions from fires and associated biomass burning. Carbon dioxide $\left(\mathrm{CO}_{2}\right)$, carbon monoxide $(\mathrm{CO})$, nitrogen oxides $\left(\mathrm{NO}_{\mathrm{x}}\right)$ and non-methane volatile organic compounds (NMVOCs) are the most important emitted gases, while black carbon (BC) and organic carbon $(\mathrm{OC})$ are the most important aerosol species [10-12]. $\mathrm{CO}_{2}$ emissions can have important implications for $\mathrm{CO}_{2}$ concentrations and understanding the carbon cycle but do not directly affect atmospheric chemistry or contribute to air quality degradation. Other carbonaceous emissions $(\mathrm{BC}, \mathrm{OC}, \mathrm{CO}$, 
NMVOCs and methane $\left(\mathrm{CH}_{4}\right)$, for which biomass burning is only a minor source) and $\mathrm{NO}_{\mathrm{x}}$ can be important for both air pollution/chemistry and climate. $\mathrm{NO}_{\mathrm{x}}, \mathrm{NMVOCs}, \mathrm{CO}$ and methane are important precursors of tropospheric ozone, which is a secondary pollutant and is not directly emitted by fires $[9 \bullet, 10]$. Such strong impacts have been demonstrated in measurement and modelling studies, on scales ranging from local to global, but significant uncertainty still remains. In this paper, we provide a review of the current understanding of such effects, focusing on the recent literature. We examine the impacts of fire emissions on the abundances of gases and aerosols and continue with a section on related radiative forcing and climate effects. Subsequently, we provide a critical discussion on future directions that will lead to better understanding of fire effects on atmospheric composition, air quality and climate, with an emphasis on improved emission estimates, emerging integrated modelling and understanding of implications for human health.

\section{Effects on Atmospheric Composition}

\section{Emission Estimates}

In an atmospheric composition context, the starting point for biomass burning studies at large scales is to estimate emissions for different species. Satellite observations are the only practical means of estimating biomass burning emissions at a global scale in a consistent way. There are currently two approaches to doing so. The first is to estimate total fuel consumption as the product of the area burned and the fuel consumed per unit area. This approach is used for the series of Global Fire Emissions Database (GFED) products [12], Fire Inventory from NCAR (FINN) [13] and, for particulate emissions, the Fire Locating and Modeling of Burning Emissions inventory (FLAMBE) [14].

The other approach is to infer fuel consumption from the fire radiative power (FRP) determined from thermal infrared measurements. The Global Fire Assimilation System (GFAS) [15•] and Quick Fire Emissions Database (QFED) [16] both use this approach. FRP-based estimates can be made in nearreal time because they use thermal infrared signatures directly, rather than an area-burned estimate based on the difference in burn scar signature before and after a fire. This makes FRP-based approaches better suited to real-time air quality forecasting systems such as the EU Monitoring Atmospheric Composition and Climate (MACC) forecasting system and the NASA GEOS-5 Aerosol Modeling and Data Assimilation System. FRP is converted to dry matter fuel consumption via biome-specific conversion factors. Emission estimates for key species, namely $\mathrm{CO}_{2}, \mathrm{CO}$, methane, $\mathrm{NO}_{\mathrm{x}}, \mathrm{OC}$ and $\mathrm{BC}$ from GFEDv3, FINNv1 and GFAS, and for total particulate matter (TPM) from the above databases and from
FLAMBE are summarised in Table 1 to provide a sense, globally, of the spread across estimates.

\section{Gases}

In the latest (Fifth) Assessment Report of the Intergovernmental Panel for Climate Change (IPCC AR5), it is stated that no estimate for the role of fire in driving long-term (e.g. Holocene) $\mathrm{CO}_{2}$ and climate changes can be given because fire is a newly studied component of carbon cycle studies [18]. A growing body of work, however, indicates an important role. Liu et al. [19] suggest that fires are one of the important atmospheric $\mathrm{CO}_{2}$ sources and contribute substantially to the global greenhouse effect. On interannual timescales, recent analysis [20] suggested that fires can be a significant driver of atmospheric $\mathrm{CO}_{2}$ variability, along with the influences of temperature and drought on net ecosystem exchange.

Non- $\mathrm{CO}_{2}$ effects of fires are also very important. To obtain emissions of different constituents for use in atmospheric modelling, emission factors are used. These represent the amount of the chemical species released per mass of biomass burned and are typically obtained from measurement campaigns in biomass burning regions [11, 21, 22]. The largest gaseous non- $\mathrm{CO}_{2}$ fire emissions are those of $\mathrm{CO}$, which are a result of incomplete combustion, especially from smouldering peat fires [12]. Amongst the short-lived constituents emitted from fires, $\mathrm{CO}$ has the largest potential to impact atmospheric composition on large geographical scales (hemispheric or even global), due to its comparatively long lifetime of a few months. Mao et al. [23] found that the global CO burden increases linearly with stepwise increases in gaseous biomass burning emissions. Using a nudged global composition-climate model in conjunction with observations, the interannual variability of the global tropospheric $\mathrm{CO}$ burden has been shown to be almost entirely driven by biomass burning emissions by Voulgarakis et al. [9•, 24], overshadowing the influence of other factors such as direct anthropogenic emissions and meteorology. The 'hot spots' of CO interannual variability [9•] were found to be the Maritime Continent and South America,

Table 1 Global mean annual emission estimates (in Tg) for key species from GFEDv3 ([12], from http://www.falw.vu/ gwerf/GFED/GFED3/ tables/), FINNv1 [13], GFAS [15•] and FLAMBE [14]

\begin{tabular}{lrrrrrrr}
\hline & $\mathrm{CO}_{2}$ & $\mathrm{CO}$ & $\mathrm{CH}_{4}$ & $\mathrm{NO}_{\mathrm{x}}$ & $\mathrm{OC}$ & $\mathrm{BC}$ & $\mathrm{TPM}$ \\
\hline GFEDv3 (2003-2011) & 6508 & 329 & 17 & 9 & 18 & 2.0 & 44 \\
FINNv1 (2005-2010) & 7323 & 373 & 18 & 13 & 23 & 2.2 & 59 \\
GFAS (2003-2008) & 6907 & 352 & 19 & 10 & 18 & 2.0 & 45 \\
FLAMBE (2006-2008) & - & - & - & - & - & - & 110 \\
\hline
\end{tabular}

GFED and GFAS emission factors are based on those of [11]; FINN emission factors are based primarily on those from [17]

TPM total particulate matter 
with strong variability also over Siberia and Canada. The interannual variations in fire-generated $\mathrm{CO}$ are closely linked to El Niño Southern Oscillation (ENSO) climate variability, which affects drought conditions primarily in Equatorial Asia and South America, and subsequently fire activity [12, 25], with both regional and global impacts. Along the same lines, observational analysis [26] showed that fires drive the interannual variability of tropical upper tropospheric $\mathrm{CO}$, with the Maritime Continent being the primary contributor.

The effect of ENSO on tropospheric $\mathrm{CO}$ via fires is also realised in regions far from the tropics. A chemistry-transport model (CTM) study [27] found that fire emissions drive 66$93 \%$ of Arctic CO interannual variability, with ENSO being a major driver. They suggest that high latitude winter/spring precipitation is influenced by ENSO, which drives fluctuations in fire activity and, therefore, fire emissions and atmospheric CO. This effect, they claim, could become more severe in the future, as boreal forest regions become hotter and drier. Without examining ENSO influences, Strode et al. [28] discuss how biomass burning strongly impacts the interannual variability of $\mathrm{CO}$ in northern mid-latitudes, which affects the ability to detect anthropogenically driven trends in CO.

Fire also has significant impacts on regional $\mathrm{CO}$ pollution levels. For Southeast Asia, Aouizerats et al. [29] found that during the fire season of 2006 (El Niño year), CO concentrations in the station of Bukit Kototabang (Sumatra) were elevated above $250 \mathrm{ppb}$ in several occasions, with the most pronounced enhancements ( $>1000 \mathrm{ppb})$ found in October. They demonstrate that these large enhancements can be simulated successfully with a regional meteorology/chemistry model using the GFED3 emission dataset, while the smaller increases due to smaller fires in earlier months cannot be fully captured. Reddington et al. [30] used back trajectories and global modelling to examine the contributions from fires to surface CO over Singapore between 2004 and 2007 and found that the highest amount of fire-produced $\mathrm{CO}$ transported to Singapore occurs in September and October, with the strongest contribution coming from fires in southern Sumatra and a secondary contribution from fires in Indonesian Borneo. They also found substantial seasonal and interannual variability in those transport patterns. Using global modelling, Marlier et al. [31] examined six tropical stations in Equatorial Asia, Africa and South America and found that including fire emissions from GFED3 improved the ability of the model to capture observed $\mathrm{CO}$ in most stations.

Other important gaseous species emitted from fires mainly include $\mathrm{NO}_{\mathrm{x}}$ and NMVOCs $[10,11,22]$, with their atmospheric effects being less thoroughly examined in the literature but with evidence that they can be important (for example, it was suggested that fires have a widespread impact on atmospheric abundances of benzene, an important NMVOC pollutant [22]). These fire-driven $\mathrm{NO}_{\mathrm{x}}$ and NMVOC increases, along with the earlier mentioned $\mathrm{CO}$ increases, can lead to significant tropospheric ozone production, since all the above-mentioned species are ozone precursors. Jaffe and Wigder [32] thoroughly examined ozone production from fires in the literature and particularly focused on observed enhancement ratios of ozone to $\mathrm{CO}\left(\mathrm{dO}_{3} / \mathrm{dCO}\right)$ as indicative of ozone production. They found $\mathrm{dO}_{3} / \mathrm{dCO}$ to range from -0.1 to 0.9 , due to factors such as fire emissions, efficiency of combustion, chemical and photochemical reactions, aerosol effects on chemistry and radiation, and local and downwind meteorological patterns. However, other recent studies suggest that positive $\mathrm{dO}_{3} / \mathrm{dCO}$ is not always an indicator of an ozone-producing region $[33,34]$, especially in cases where there is substantial CO loss in a plume due to intense production of $\mathrm{OH}$ from ozone. Parrington et al. $[35,36]$ discussed in detail ozone production in fire plumes in North America and the northern Atlantic. Their analysis suggests that plumes younger than 4 days feature low ozone production efficiencies that increase for older plumes, associating this feature with the relatively quick reduction of aerosol loading with plume age. Aerosols attenuate shortwave radiation and thus slow down the photolysis of $\mathrm{NO}_{2}$, which is essential for ozone production in the troposphere, while also they provide surfaces for heterogeneous uptake and loss of ozone and $\mathrm{NO}_{\mathrm{y}}$ (collective name for oxidised forms of nitrogen in the atmosphere, which facilitate ozone production) [37].

Global chemistry-climate model analysis [23] found that global tropospheric ozone production and burden linearly increase with fire emissions, as a result of the high NMVOC/ $\mathrm{NO}_{\mathrm{x}}$ ratio in such emissions. They showed that co-emission of trace gases and aerosols from present-day biomass burning increases the global tropospheric ozone burden by $5.1 \%$. Biomass burning aerosols actually drive decreases in global ozone burden in their model, primarily due to heterogeneous processes and not due to photolysis effects, which are not important globally, but are potentially important regionally. In terms of interannual variability, Voulgarakis et al. [9•] suggested that fire emissions had little influence on global variations of tropospheric ozone, due to global ozone being a wellbuffered quantity in atmospheric models.

The effect of fire emissions on regional ozone pollution levels can be significant. A series of studies from the Western USA provide a good illustration. Work using a statistical model along with the WRF-Chem regional weather/ chemistry model demonstrated the large influence of fires on ozone production in the Western USA, highlighting the important role of peroxyacetyl nitrate $\left(\mathrm{PAN}\right.$, a reservoir of $\mathrm{NO}_{\mathrm{x}}$ ) in this process [38]. In one case in June 2008, up to a $60 \mathrm{ppbv}$ increase in Reno, Nevada, resulted from fires in California. Similarly, Singh et al. [39] examined the summer of 2008 and found that the highest ozone mixing ratios in Los Angeles (170 ppbv) were measured in a case where biomass burning influences were strong. Observational analysis by Wigder et al. [40] from a ground station in Oregon found significant 
positive $\Delta \mathrm{O}_{3} / \Delta \mathrm{CO}$ ratios in plumes originating from wildfires in the Western USA and Canada, especially in cases where the plumes where confined to the boundary layer.

Still in the northern mid-latitudes (Mediterranean), Hodnebrog et al. [41] examined the impact of the large fires in Greece in the summer of 2007 and showed that they may have impacted ozone pollution levels by up to $18 \mathrm{ppbv}$. Over Portugal, simulations of ozone levels improved by $15 \%$ when accounting for fire emissions [42]. Surface and satellite observations along with backward trajectory analysis [43] showed that $56 \%$ of the acute pollution events with enhanced ozone at a surface station in Nepal were likely to be affected by emissions from open fires along the Himalayan foothills, the Indian Subcontinent and the Northern Indo-Gangetic Plain. In subtropical Taiwan, a study has calculated higher ozone by $8 \mathrm{ppbv}$ in March in air masses that have passed over fire regions in the Mekong [44]. Closer to the equator, it has been found that high ozone episodes in Malaysia are associated with transport of biomass burning plumes from Sumatra [45]. However, on average, Marlier et al. [31] found no substantial improvements in the performance of a global model against observations in terms of tropical surface ozone when including fire emissions in the model.

Biomass burning emissions can affect other important constituents involved in atmospheric chemistry processes, such as the hydroxyl radical $(\mathrm{OH})$, which is the most important oxidant in the troposphere. Voulgarakis et al. [9•] showed that most of the interannual variability in global tropospheric mean $\mathrm{OH}$ concentrations is driven by biomass burning, as a result of the strong global CO fluctuations (CO consumes $\mathrm{OH}$ during its oxidation) due to ENSO-modulated fire emissions. El Niño and the associated intense burning in the tropics (and, to some extent, the extratropics) can also lead to increased methane levels, both due to anomalous methane emissions and due to the longer methane lifetime resulting from increased global $\mathrm{CO}$ levels ( $\mathrm{CO}$ consumes $\mathrm{OH}$ that could have otherwise contributed to methane loss) [46]. However, this effect on methane is significant only in very strong El Niño events (such as that of 1997-1998), and, in general, fire contributions are estimated to have a relatively small impact on the methane budget [47].

\section{Aerosols}

Fires are also responsible for emissions of large amounts of aerosol constituents, especially BC and OC [11, 12]. Globalscale studies focusing on the large-scale effects of fires on aerosol abundances have been surprisingly sparse. The recent model analysis by Jacobson [48] which focused on climate effects found that biomass burning increased global mean absorbing aerosol optical depth (AAOD) by $\sim 55 \%$ and total aerosol optical depths (AOD) by $\sim 15 \%$. When it comes to interannual variability, recently, Voulgarakis et al. [9•] suggested that fires are a strong driver of the global aerosol burden but only when excluding the heavy components of dust and sea salt from the calculation. ENSO was again suggested as an important influence on this variability, as it was also earlier discussed by Ji and Stocker [49] who mainly focused on the tropical aerosol index.

There has been a much larger number of studies on regional effects of fires on aerosols. In recent years, there has been substantial focus on the tropics. For the Brazilian Amazon, using surface in situ measurements, it was found [50] that concentrations of submicron aerosols reached $100 \mu \mathrm{g} \mathrm{m}^{-3}$ during biomass burning events in September/October 2012, with organic aerosols largely dominating the aerosol mass. A similar finding about the dominance of organic particles in this environment was also demonstrated by Atraxo et al. [51]. Similarly, in Southeast Asia, Lin et al. [52] found that sites that are heavily impacted by biomass burning experience elevated fine particle concentrations (with particles with diameters less than $2.5 \mu \mathrm{m}$, namely $\mathrm{PM}_{2.5}$, exceeding $45 \mu \mathrm{g} \mathrm{m}^{-3}$ on average), dominated by organic mass enhancements. In Singapore, it has been suggested [30] that fire emissions from Indonesia account for drastic enhancements of $\mathrm{PM}_{2.5}$ pollution, as was also the case for CO. More recently, regional climate modelling revealed that Indonesian fires contributed to 17 days exceeding $50 \mu \mathrm{g} \mathrm{m}^{-3}$ concentrations of $\mathrm{PM}_{2.5}$ in the July-October period of 2006 in Singapore [29]. Using global modelling, but focusing on the tropics, Marlier et al. [31] found that a model's ability to capture aerosol optical depths measured from AeroNet in all tropical land regions (Equatorial Asia, Africa, South America) improved drastically when including fire emissions in the simulations, in contrast to what happened with ozone, whose abundances are more buffered by other processes.

Substantial contributions from fires to atmospheric aerosol abundances have also been suggested for the extratropics. In the Southwestern and Western USA, fires are a common reason behind intense pollution episodes; for example, Zauscher et al. [53] showed that in October 2007, fires led to the concentrations of fine $(<400 \mathrm{~nm})$ particles reaching up to $148 \mu \mathrm{g} \mathrm{m}^{-3}$ in San Diego. In Oregon, an observational study found that fires lead to sizeable aerosol enhancements, and simultaneous analysis of $\Delta \mathrm{PM}_{1} / \Delta \mathrm{CO}$ ratios suggested significant secondary production in the biomass burning plumes that were less than 2 days old [40]. Using receptor models, which are common tools in air quality studies, Gibson et al. [54] quantified that the median boreal fire contribution to surface $\mathrm{PM}_{2.5}$ in Halifax, Canada, during summer 2011 was $0.14 \mu \mathrm{g} \mathrm{m}^{-3}$. Focusing on interannual timescales, Spracklen et al. [55] had earlier shown that western US organic aerosol variability is mainly driven by fires. Yue et al. [56], using a regression-based fire algorithm in conjunction with a CTM, estimated future impacts of fires on western US aerosols and found that changes in fire emissions may increase 
summertime surface $\mathrm{OC}$ by $46-70 \%$ and $\mathrm{BC}$ by $20-27 \%$ by mid-21st century relative to the present day, with even higher increases found for extreme episodes.

In Europe, fire contributions to aerosol pollution are more prominent in the Mediterranean basin in the summer. Bougiatioti et al. [57] found that biomass burning can contribute almost half of the organic aerosol mass at the island of Crete during periods with significant fire influence and stress the importance of fires that occur remotely, in other parts of Greece and the Mediterranean in general. Strong increases (by $40-50 \%$ on average) of aerosol concentrations were found in Athens, Greece, as a result of large fires in Russia and Ukraine in August 2010 [58]. Similarly to the eastern Mediterranean, fires have been shown to have sizeable effects in southwestern Europe. As was the case for ozone, Martins et al. [42] showed that simulations of $\mathrm{PM}_{10}$ levels in Portugal improved by $20 \%$ when accounting for fire emissions. For Spain, it has been found that biomass burning is responsible for about $20 \%$ of organic carbon levels in $\mathrm{PM}_{10}, \mathrm{PM}_{2.5}$ and $\mathrm{PM}_{1}$ on an annual basis [59]. Studies have shown that biomass burning can have substantial contributions even in the north of Europe. A particularly prominent example is the fire-driven air pollution episode of summer 2010 in western Russia, which affected not only Russia itself but also other parts of Northern Europe [60] and even southern Europe [58], as mentioned earlier. For a boreal forest in Hyytiälä, Finland, using two independent analytical methods and three separate statistical methods, Corrigan et al. [61] showed that biomass burning is responsible for $25 \%$ of submicron organic aerosols in the area, especially in the relatively warm and dry months of summer.

In mid-latitude Asia, the contribution of fires to aerosol pollution can also be significant, though less so compared to parts of North America and Europe. As was the case for ozone, Putero et al. [43] showed that BC levels in Nepal can be strongly impacted by open vegetation fires in the broader region. Further north, in the Arctic, fires have been shown to be a major contributor to $\mathrm{BC}$ and $\mathrm{OC}$ increases way above the regional background levels, with important implications for radiative forcing $[62,63]$.

The Southern Hemisphere mid-latitudes are exposed to less biomass burning pollution, due to the lower fraction of land mass compared to the Northern Hemisphere. However, due to the generally low levels of background pollution, fire events can stand out as very important for regional aerosol pollution extremes, e.g. in Australia [64].

\section{Effects on UT/LS Composition}

The most energetic fires can inject smoke directly into the upper troposphere and are referred to as pyroconvective plumes. They were discovered in the late 1990s over northwestern Canada and are routinely detected over North
America, Russia and Australia [65], where the combination of high fuel loads and strong synoptic disturbances provide conditions necessary for explosive fires and high altitude injection. Emissions from tropical biomass burning can reach high altitudes, but to the best of our knowledge, this occurs mainly from horizontal advection into regions of deep convection rather than direct upper troposphere/lower stratosphere (UT/LS) injection [66].

Pyroconvective events are rare. Sofiev et al. [67] estimated that globally $90 \%$ of emissions were released below $3 \mathrm{~km}$. For 2004-2005 over North America, it was estimated that $8 \%$ of smoke plumes reached more than $2.5 \mathrm{~km}$ above the boundary layer [68]; only a small number of these are lofted directly to the upper troposphere. Strode et al. [28] indeed found that the influence on tropospheric $\mathrm{CO}$ due to biomass burning decreases with height, being smaller at $500 \mathrm{hPa}$ than at the surface.

However, pyroconvective plumes are injected directly into the geostrophic flow and drier air; they are longer lived and can be transported thousands of kilometres. The plumes can remain intact as they cross the tropopause into the lower stratosphere. An important recent example was the devastating 2009 Black Saturday firestorm in southeast Australia. Emissions were injected into upper troposphere over only a 4-6-h period, but the plume's impact persisted for months. The plume was detected in the lower stratosphere 3 weeks after the initial emission pulse, standing out over Africa from background levels of CO from Aura MLS [69], aerosolsensitive radiances from Odin-OSIRIS [70] and HCN from Envisat-MIPAS [71]. The aerosol signature of the fires persisted until July 2009 in CALIOP scattering ratio measurements, ranking in strength between the small Kasatochi and Sarychev volcanic eruptions [72]. Pyroconvective plumes are likely a secondary source of pollutants in the stratosphere relative to volcanic eruptions, although a systematic comparison of their contribution has not been done with a full complexity composition-climate model. Their impact could also become a greater concern in future climates [73] with higher fire danger [7].

\section{Effects on Radiative Forcing and Climate}

Fires can impact radiative forcing (RF) and climate through a variety of interactions that can involve both the atmosphere and the land surface [1]. Here, we will not focus on the latter (effects on non-fire vegetation carbon fluxes, albedo, transpiration) but will discuss in more detail the radiation and climate impacts through emissions of key constituents. Air pollution and climate are linked through a variety of interactions, in both directions: (a) changes in temperature, humidity, rainfall, wind patterns and radiation affecting the chemistry, microphysics and transport of pollutants (climate affecting pollution) and, 
(b) in turn, pollutants directly (in the case of greenhouse gases and aerosols) or indirectly (in the case of constituents impacting greenhouse gases and aerosols) exerting radiative forcing and subsequently impacting temperatures, circulation and the hydrological cycle (pollution affecting climate) $[74$, 75]. The latter direction (b) is of immediate relevance to the topic of this review.

There has been a range of localised and regional studies investigating radiative effects of fire emissions, especially of aerosols. Observations revealed a dramatic top-of-theatmosphere (TOA) radiative effect (up to $-65 \mathrm{Wm}^{-2}$ on average) from aerosols emitted in the August 2010 Russian wildfires [76]. The average TOA effect of major outbreaks of fires in various parts of Asia in spring 2008 was estimated to be $-12 \mathrm{Wm}^{-2}$ by using air quality and radiative transfer modelling [77]. In the tropics, using satellite information and radiative transfer modelling, the direct radiative impact of Amazonian biomass burning aerosols was estimated to be $-5.6 \mathrm{Wm}^{-2}$ on average over a period of 10 years [78]. The latter study also mentions that locally and for high aerosol loadings, this effect reached $20 \mathrm{Wm}^{-2}$.

The effect of biomass burning aerosols on clouds, which, in turn, affect radiation and climate, has been a topic of debate. Koren et al. [79] discussed two different regimes of aerosolcloud interactions over the Amazon. They suggest that lowaerosol conditions favour a rapid increase of cloud fraction as a function of aerosol loading due to microphysical effects, and high-aerosol conditions feature cloud decreases with aerosol loading, due to the atmospheric stabilisation by semi-direct effects of smoke particles (the latter has recently also been observed as the major mechanism in tropical Africa [80]). Recent observational evidence has further confirmed this theory [81]. Apart from the above-mentioned effects, however, studies have also highlighted the impacts of aerosols on heating gradients and circulation, which can potentially be even more important $[82,83]$.

On a global scale, little systematic work has been pursued to estimate RF from fire emissions. The only component of fire-related RF for which the latest IPCC report (AR5) [74] provides an estimate is that of aerosols, and even for that the estimate is very uncertain $\left( \pm 0.20 \mathrm{Wm}^{-2}\right.$ for preindustrial to present-day RF). The report also notes that this relatively small mean aerosol RF is a consequence of rather strong forcings of opposite signs by BC (positive) and OC (negative). We also stress that regional effects of biomass burning aerosols can be much larger than their global impacts, given the short aerosol lifetimes. Fire-generated (from precursors such as $\mathrm{CO}$, NMVOCs, $\mathrm{NO}_{\mathrm{x}}$ and methane) tropospheric ozone and $\mathrm{CO}_{2}$ $\mathrm{RF}$ estimates are not provided by IPCC AR5, because interactive fire has not been included as a component in global climate modelling efforts so far [18].

The only systematic study to date of the global radiative effect and preindustrial-to-present-day RF from a broad spectrum of impacts from wildfires has been published by Ward et al. [84•]. The authors used a land-surface model to estimate preindustrial, present-day and future fire emissions and subsequently fed these emissions to an atmospheric model to calculate RF. They estimated that preindustrial fires were responsible for a global radiative effect of $-1 \mathrm{Wm}^{-2}$ with respect to a preindustrial climate without fires, with the largest contribution $\left(-1.6 \mathrm{Wm}^{-2}\right)$ resulting from aerosol indirect effects (AIEs) through cloud increases. The second most important component is that of $\mathrm{CO}_{2}$, which results in a radiative effect of $+0.83 \mathrm{Wm}^{-2}$. The fire impact between 1850 and 2000 was also dominated by AIE, which caused a $\mathrm{RF}$ of $+0.6 \mathrm{Wm}^{-2}$. However, that is not caused by substantial changes in fire-emitted aerosols but by increases in anthropogenic aerosols, which caused the cooling potential of fire aerosols to decrease. This effect was discussed more recently [85], with a broader perspective on all natural aerosol radiative effects. Between 1850 and 2100, Ward et al. estimated a firedriven $\mathrm{RF}$ of about $+0.2 \mathrm{Wm}^{-2}$, with the aerosol direct effect (ADE) being key, but also with a large uncertainty depending on the future climate scenario influencing fire activity [84•]. A variety of the factors involved in the modelling used by that study (fire parameterisations, treatment of aerosols and AIE, $\mathrm{OH}$ representation which would affect ozone and methane $\mathrm{RF}$ ) are heavily model-dependent, and therefore, it is important to pursue further model studies of this kind.

The later study by Jacobson [48] performed shorter (20 years) transient global model simulations and found that total biomass burning may be causing a net global warming of $0.4 \mathrm{~K}(\sim 1 \mathrm{~K}$ in the Arctic), because the warming effects (cloud and aerosol absorption; semi-direct) outweigh negative effects (ADE and AIE). However, both because that study is for a short, transient period and because it included anthropogenic biomass burning as well in the calculations, it is not directly comparable to the study by Ward et al. [84•]. Mao et al. [23], who used present-day global simulations, found that the global radiative effect from fire emissions due to aerosols and short-lived gases varies non-linearly with biomass burning strength. They estimated a present-day net radiative effect of $-0.19 \mathrm{Wm}^{-2}$ from such emissions, dominated by ADE and AIE, and compensated by methane increases (due to $\mathrm{CO}$ increases and $\mathrm{OH}$ decreases) and methane-induced increases in ozone and stratospheric water vapour. This changes to a positive effect when fire emissions are increased by five times above their present-day levels. The figure is much smaller for aerosols and substantially larger for methane compared to what Ward et al. [84-] found for those radiative effects in a preindustrial atmosphere, which again highlights the importance for further studies on this topic.

It has also been suggested that fire emissions can have effects on large-scale circulation. Specifically, a modelling study suggested that the Hadley Cell circulation can be weakened due to the heating of the atmosphere and cooling of the 
surface that smoke aerosols cause in the tropics, with large precipitation reductions near the equator offset by smaller increases north and south of it [86]. The area of study of fire effects on circulation and precipitation on large scales is very much at its infancy and requires a lot more investigation in future research.

\section{Future Directions}

\section{Improvements in Emissions}

Aside from the TPM estimates, general consistency across global emission estimates in Table 1 can obscure larger differences regionally and over shorter periods. For the Black Saturday fires in Australia described above, it was found [87] that GFEDv3 estimates were at least a factor of two greater than FINN v1 estimates for all emitted species and that both estimates were likely too low by at least a factor of $50 \%$ when their burned area was compared to more detailed, ground-truth, surveys. Zhang et al. [88] found that over the USA, their mid-infrared GOES-based FRP estimates of fuel consumption were higher than GFED3.1 by a factor of 1.23.3 for 1997-2010. Differences or biases in emissions can translate into large spread in modelled composition and discrepancies with trace gas and aerosol measurements. Globally, it has been required [15॰] that GFAS OC and BC estimates be scaled upward by a factor of 3.4 when input into the MACC system to obtain reasonable agreement with MODIS AOD retrievals, suggesting that the bias was aerosol-specific, given reasonable agreement with several trace gas species. Similarly, large sensitivity to emission estimates and discrepancies with composition measurements were recently found for the Moscow peat fires of 2010 [89], over the Mekong region from 2004 to 2009 [30] and northern sub-Saharan Africa [90].

The accuracy of burned area estimates will be limited by the sampling frequency and spatial resolution of the instruments from which they are derived. The MODIS instruments on board Aqua and Terra, for example, operate in a low-earth, polar orbit, which provides higher spatial resolution but limited sampling coverage. Because each instrument has a twicea-day sampling frequency, fires can be missed, especially at lower latitudes because of the swath path [13]. Accounting for these gaps is difficult and currently somewhat ad hoc, as is accounting for possible diurnal biases when using data from both MODIS instruments, although statistical techniques have recently been explored to that end [91]. Emission estimates will ultimately continue to benefit from improved fire detection using instruments on board geostationary satellites such as GOES, Meteosat and MTSAT for combined near-global coverage [92] and with the combination of instruments such as SEVERI with instruments such as MODIS onboard polar orbiting satellites [93] and instruments with higher spatial resolution and coverage such as VIIRS [94] and the anticipated SLSTR [95]. Conversely, there is value in re-analysing older satellite data for the purpose of improving long-term estimates, as was done in [96] over Kalimantan, Indonesia, using AVHRR data from 1980 to 2000. More use could also be done in comparing satellite-based estimates of fire characteristics to those from fire-fighting agencies when they exist, particularly in validating emissions from smaller fires and with higher temporal variability $[31,97]$.

For FRP-based estimates, further studies of the dependence of combustion rate on fuel condition will be helpful [88], as will further uncertainty characterisation [98]. The fuel consumption database of van Leeuwen et al. [99] is an important resource for validating modelled fuel consumption across different biomes and under different fuel conditions. Emission factor estimates will also benefit from further measurement [87] and characterisation of biome-specific emission factors for different constituents [100] (Fig. 1). The modelled fate of these emissions will benefit from improved injection height models and validation against observations [101], with a first-order goal to distinguish between smoke released into the boundary layer from that injected into the free troposphere.

\section{Emerging Integrated Modelling}

Past and future climate change, as well as interannual climate variability, could play an important role in driving changes in fire activity, on both regional and global scales. Fires can, in turn, affect climate via a variety of feedbacks, such as emissions of long-lived gases, short-lived gases, aerosols and impacts on the land surface. The need for integrated Earth system

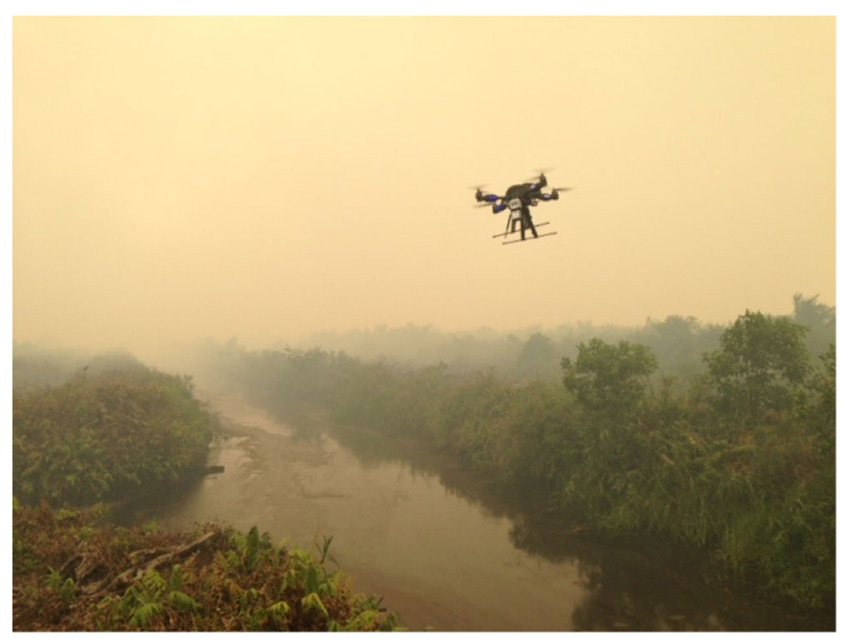

Fig. 1 Remote-controlled drone over South Sumatra during the brief haze event of September-October 2014. Trace gas measurements from the drone are being used to better constrain emission factors from tropical peat burning. (Courtesy of Guido van der Werf, VU Amsterdam) 
modelling in order to understand the role of fire in the Earth system has been stressed in the past [1]. This need still remains to be fulfilled. We know of no work to date that assesses such feedbacks in a fully coupled modelling system that simulates fire, atmospheric composition, climate and the land surface simultaneously.

However, there has been substantial progress in developing models that are suitable for implementation in global climate modelling. The fire module of the Canadian Terrestrial Ecosystem Model [102] estimates the probability of fire occurrence depending on fuel availability and fuel moisture and presence of an ignition source (anthropogenic or natural). Pechony and Shindell [3] developed a fire model that relies on a simple parameterisation involving temperature, humidity, precipitation and the underlying vegetation density, with an option to take into account natural (lightning) and human ignitions, as well as human suppression. The option to use sophisticated but more computationally expensive global fire models has also become available in recent years, with one such example being LPFIRE, a new process-based fire model combining features from the LPJ family of fire models (primarily SPITFIRE [103]), in which fire is simulated as a function of ignitions and fire susceptibility, calculated from fuel amount, physical properties and moisture content.

Since the climate variables can be predicted online by an atmospheric model and the vegetation density can be predicted by a land surface model, which are both components that typically exist in current Earth system models (ESMs), fire parameterisations such as the above can be coupled with ESMs relatively easily. Simultaneously, such models can be developed further to calculate fire emissions in addition to fire occurrence and burned area, such as in studies $[6,84 \cdot]$ that used a modified version of the Community Land Model version 3.5 with a carbon-nitrogen biogeochemical model and estimated fire emission changes between the past, present and future.

Currently, the above mechanistic fire occurrence/emission models are being implemented in some key global ESMs. This development will allow for including fire as a component in global climate simulations and the potential to improve climate predictions and will, at the same time, allow for studying global and regional changes in atmospheric composition and fire-generated pollution.

Major advances in fire modelling at a global scale will also depend on advances in the 'core' atmospheric components, such as improvements to subgrid parameterisations of convection and turbulence. Fire size and fuel consumption will be estimated less from empirical relationships and more from dynamical fire spread models, which currently exist only for high-resolution limited-domain models [104]. The simulated meteorology, in turn, will respond to fluxes of momentum, heat and emissions from the fire. Lightning activity and plume heights will be estimated accordingly. This will make more sense as convective super-parameterisations [105] become more commonplace, but this is likely to be a decade away for CMIP-grade production GCMs and will require commensurate improvements in fuel characterisations.

\section{Assessing Health and Other Impacts}

Fires can have wide-ranging effects on surface air quality, both in the tropics and extra-tropics (see earlier section). In general, health effects of key anthropogenic pollutants such as particulate matter (i.e. aerosols) and ozone have been investigated extensively, with some studies even documenting global effects, e.g. [106]. A few studies have specifically focused on the impacts of fire emissions on health, such as the work by Marlier et al. [107], which examined climate variability (specifically, El Niño) as a potential driver of such effects in Southeast Asia. A key study [108] provided estimates of global mortality due to fire emissions, using an atmospheric model in conjunction with satellite observations to estimate pollutant levels and suggested that landscape fires lead to 339,000 deaths annually, with the most vulnerable regions being subSaharan Africa and Southeast Asia and the situation being worse during El Niño years. These studies have mostly focused on particulate matter (PM) and ozone effects, but as we have noted earlier, health effects from fires could also result from emissions of toxic NMVOCs, such as benzene [22].

The link between climate variations and health impacts from fires has implications for future population health [109]. Emerging integrated modelling capabilities, where future fire activity is simulated simultaneously with climate and where atmospheric composition effects of such fire changes are also calculated, will facilitate studying the influences of climate change on health. Furthermore, such advances are expected to trigger a closer dialogue between scientists working on the physical aspects of climate change and fire, and public health scientists. On a broader perspective, crossfertilisation and dialogue between different communities can facilitate the assessment and understanding of other impacts of fires not immediately linked to air pollution, such as those on ecosystems, agriculture, infrastructure and the economy.

\section{Conclusions}

The effects of fire on atmospheric composition depend on the region of emission and constituent of interest. North America and Europe have been investigated more thoroughly, while Southeast Asia, South America and Siberia have received specific scientific attention more recently. Africa, remote oceanic areas and polar regions have been far less studied, and the understanding of such effects there relies heavily on satellite information and modelling. The species that have been more 
extensively investigated are ozone and aerosols (especially $\mathrm{BC}$ ), with fewer studies focusing on other constituents, such as NMVOCs and $\mathrm{NO}_{\mathrm{x}}$. Fires can lead to substantial radiative forcing due to their emissions, but the magnitude of those effects remains uncertain. Even more uncertain and unexplored are the climate responses caused by fire emissions. It is therefore important to conduct further modelling for understanding such effects better and to aim for integrated systems that include fire as a component interacting with climate, atmospheric chemistry and the biosphere. For this modelling to be accurate, however, we need sustained observations that will lead to a better characterisation of the emissions from fires. Currently and due to substantial disagreements between emission datasets provided by different groups, we recommend that modelling studies based on single emission estimates should be interpreted cautiously. Nevertheless, the advances that have been made over the past decade on both the observational and the modelling front are remarkable, and, over the next decades, the community is expected to be gaining progressively more insight into the role of fire in the Earth system and how it affects human society and ecosystems.

Acknowledgments RF was supported by the NASA Atmospheric Chemistry Modeling and Analysis Program Grant NNX13AD46G. AV wishes to thank the European Commission's Marie Curie International Research Staff Exchange Scheme (IRSES) for partly funding the interactions with RF under the project titled Regional climate-air quality interactions (REQUA), PIRSES-GA-2013-612671.

Conflict of Interest On behalf of all authors, the corresponding author states that there is no conflict of interest.

\section{References}

Papers of particular interest, published recently, have been highlighted as:

- Of importance

1. Bowman DMJS, Balch JK, Artaxo P, Bond WJ, Carlson JM, Cochrane MA, et al. Fire in the earth system. Science. 2009;324: 481-4.

2. Keywood M, Kanakidou M, Stohl A, Meyer CP, Torseth K, Edwards D, et al. Fire in the air-biomass burning impacts in a changing climate. Crit Rev Environ Sci Technol. 2012;43(1):4083. doi:10.1080/10643389.2011.604248.

3. Pechony O, Shindell DT. Fire parameterization on a global scale. J Geophys Res. 2009;114, D16115. doi:10.1029/2009jd011927.

4. Bistinas I, Harrison SP, Prentice IC, Pereira JMC. Causal relationships versus emergent patterns in the global controls of fire frequency. Biogeosciences. 2014;11:5087-101. doi:10.5194/bg-115087-2014.

5. Pechony O, Shindell DT. Driving forces of global wildfires over the past millennium and the forthcoming century. Proc Nat Acad Sci. 2010;107:19167-70. doi:10.1073/pnas.1003669107.
6. Kloster S, Mahowald NM, Randerson JT, Lawrence PJ. The impacts of climate, land use, and demography on fires during the 21st century simulated by CLM-CN. Biogeosciences. 2012;9:509-25. doi:10.5194/bg-9-509-2012.

7. Flannigan MD, Cantin AS, de Groot WJ, Wotton M, Newbery A, Gowman LM. Global wildland fire season severity in the 21 st century. For Ecol Manag. 2013;294:64-71.

8. Giglio L, Randerson JT, van der Werf GR, Kasibhatla PS, Collatz GJ, Morton DC, et al. Assessing variability and long-term trends in burned area by merging multiple satellite fire products. Biogeosciences. 2010;7:1171-86. doi:10.5194/bg-7-1171-2010.

9. Voulgarakis A, Marlier ME, Faluvegi G, Shindell DT, Tsigaridis K (2015), Biomass burning as a driver of the interannual variability of tropospheric trace gases and aerosols, (submitted to J Geophys Res. The first study to systematically investigate the role of fire as a driver of interannual variability of global and regional abundances of tropospheric gases and aerosols, using modelling in conjunction with satellite and in-situ observations.

10. Crutzen PJ, Andreae MO. Biomass burning in the tropics: impact on atmospheric chemistry and biogeochemical cycles. Science. 1990;250:1669-78.

11. Andreae MO, Merlet P. Emission of trace gases and aerosols from biomass burning. Glob Biogeochem Cycles. 2001;15:955-66.

12. van der Werf GR, Randerson JT, Giglio L, Collatz GJ, Mu M, Kasibhatla PS, et al. Global fire emissions and the contribution of deforestation, savanna, forest, agricultural, and peat fires (1997-2009). Atmos Chem Phys. 2010;10:11707-35. doi:10. 5194/acp-10-11707-2010.

13. Wiedinmyer C, Akagi SK, Yokelson RJ, Emmons LK, Al-Saadi JA, Orlando JJ, et al. The Fire INventory from NCAR (FINN): a high resolution global model to estimate the emissions from open burning. Geosci Model Dev. 2011;4(3):625-41. doi:10.5194/ gmd-4-625-2011.

14. Reid JS, Hyer EJ, Prins EM, Westphal DL, Zhang JL, Wang J, et al. Global monitoring and forecasting of biomass-burning smoke: description of and lessons from the fire locating and modeling of burning emissions (FLAMBE) program. IEEE J Sel Topics Appl Earth Observ Remote Sens. 2009;2(3):144-62. doi: 10.1109/jstars.2009.2027443.

15. Kaiser JW, Heil A, Andreae MO, Benedetti A, Chubarova N, Jones L, et al. Biomass burning emissions estimated with a global fire assimilation system based on observed fire radiative power. Biogeosciences. 2012;9(1):527-54. doi:10.5194/bg-9-527-2012. A key recent study providing global emissions estimates by assimilating Fire Radiative Power (FRP) observations from the MODIS satellite instruments, which can significantly improve real-time air quality forecasting systems.

16. Darmenov A, da Silva A. The Quick Fire Emissions Dataset (QFED) Documentation of versions 2.1, 2.2 and 2.4. NASA Technical Report Series on Global Modeling and Data Assimilation. NASA TM-2013-104606. 2013;32:183.

17. Akagi SK, Yokelson RJ, Wiedinmyer C, Alvarado MJ, Reid JS, Karl T, et al. Emission factors for open and domestic biomass burning for use in atmospheric models. Atmos Chem Phys. 2011;11:4039-72. doi:10.5194/acp-11-4039-2011.

18. Ciais P, Sabine C, Bala G, Bopp L, Brovkin V, Canadell J, et al. Carbon and other biogeochemical cycles. In: Stocker TF, Qin D, Plattner G-K, Tignor M, Allen SK, Boschung J, Nauels A, Xia Y, Bex V, Midgley PM, editors. Climate Change 2013: the physical science basis. Contribution of working group I to the fifth assessment report of the Intergovernmental Panel on Climate Change. Cambridge: Cambridge University Press; 2013.

19. Liu Y, Goodrick S, Heilman W. Wildland fire emissions, carbon, and climate: wildfire-climate interactions. For Ecol Manag. 2013;317:80-96. doi:10.1016/j.foreco.2013.02.020. 
20. Keppel-Aleks G, Wolf AS, Mu M, Doney SC, Morton DC, Kasibhatla PS, et al. Separating the influence of temperature, drought, and fire on interannual variability in atmospheric $\mathrm{CO}_{2}$. Glob Biogeochem Cycles. 2014;28:1295-310. doi:10.1002/ 2014GB004890.

21. Simpson IJ, Akagi SK, Barletta B, Blake NJ, Choi Y, Diskin GS, et al. Boreal forest fire emissions in fresh Canadian smoke plumes: C1-C10 volatile organic compounds (VOCs), CO2, CO, $\mathrm{NO} 2, \mathrm{NO}, \mathrm{HCN}$ and $\mathrm{CH} 3 \mathrm{CN}$. Atmos Chem Phys. 2011;11:6445-63. doi:10.5194/acp-11-6445-2011.

22. Lewis AC, Evans MJ, Hopkins JR, Punjabi S, Read KA, Purvis $\mathrm{RM}$, et al. The influence of biomass burning on the global distribution of selected non-methane organic compounds. Atmos Chem Phys. 2013;13:851-67. doi:10.5194/acp-13-851-2013.

23. Mao J, Horowitz LW, Naik V, Fan S, Liu J, Fiore AM. Sensitivity of tropospheric oxidants to biomass burning emissions: implications for radiative forcing. Geophys Res Lett. 2013;40: 1241-6. doi:10.1002/grl.50210.

24. Voulgarakis A, Savage NH, Wild O, Braesicke P, Young PJ, Carver GD, et al. Interannual variability of tropospheric composition: the influence of changes in emissions, meteorology and clouds. Atmos Chem Phys. 2010;10:2491-506. doi:10.5194/ acp-10-2491-2010.

25. Field RD, van der Werf GR, Shen SSP. Human amplification of drought-induced biomass burning in Indonesia since 1960. Nat Geosci. 2009;2(3):185-8.

26. Huang L, Fu R, Jiang JH. Impacts of fire emissions and transport pathways on the interannual variation of $\mathrm{CO}$ in the tropical upper troposphere. Atmos Chem Phys. 2014;14:4087-99. doi:10.5194/ acp-14-4087-2014.

27. Monks SA, Arnold SR, Chipperfield MP. Evidence for El NiñoSouthern Oscillation (ENSO) influence on Arctic CO interannual variability through biomass burning emissions. Geophys Res Lett. 2012;39, L14804. doi: 10.1029/2012GL052512.

28. Strode SA, Pawson S. Detection of carbon monoxide trends in the presence of interannual variability. J Geophys Res Atmos. 2013;118:12257-73. doi:10.1002/2013JD020258.

29. Aouizerats B, van der Werf GR, Balasubramanian R, Betha R. Importance of transboundary transport of biomass burning emissions to regional air quality in Southeast Asia during a high fire event. Atmos Chem Phys. 2015;15:363-73. doi:10.5194/acp-15363-2015.

30. Reddington CL, Yoshioka M, Balasubramanian R, Ridley D, Toh YY, Arnold SR, et al. Contribution of vegetation and peat fires to particulate air pollution in Southeast Asia. Environ Res Lett. 2014;9:094006. doi:10.1088/1748-9326/9/9/094006.

31. Marlier ME, Voulgarakis A, Shindell DT, Faluvegi G, Henry CL, Randerson JT. The role of temporal evolution in modeling atmospheric emissions from tropical fires. Atmos Environ. 2014;89: 158-68. doi:10.1016/j.atmosenv.2014.02.039.

32. Jaffe DA, Wigder NL. Ozone production from wildfires: a critical review. Atmos Environ. 2012;51:1-10. doi:10.1016/j.atmosenv. 2011.11.063.

33. Voulgarakis A, Telford PJ, Aghedo AM, Braesicke P, Faluvegi G, Abraham NL, et al. Global multi-year $\mathrm{O}_{3}-\mathrm{CO}$ correlation patterns from models and TES satellite observations. Atmos Chem Phys. 2011;11:5819-38. doi:10.5194/acp-11-5819-2011.

34. Zhang B, Owen RC, Perlinger JA, Kumar A, Wu S, Val Martin M, et al. A semi-Lagrangian view of ozone production tendency in North American outflow in the summers of 2009 and 2010. Atmos Chem Phys. 2014;14:2267-87. doi:10.5194/acp-14-2267-2014.

35. Parrington M, Palmer PI, Henze DK, Tarasick DW, Hyer EJ, Owen RC, et al. The influence of boreal biomass burning emissions on the distribution of tropospheric ozone over North America and the North Atlantic during 2010. Atmos Chem Phys. 2012;12:2077-98. doi:10.5194/acp-12-2077-2012.
36. Parrington M, Palmer PI, Lewis AC, Lee JD, Rickard AR, Di Carlo P, et al. Ozone photochemistry in boreal biomass burning plumes. Atmos Chem Phys. 2013;13:7321-41. doi:10.5194/acp-13-7321-2013.

37. Konovalov IB, Beekman M, D'Anna B, George C. Significant light induced ozone loss on biomass burning aerosol: evidence from chemistry-transport modeling based on new laboratory studies. Geophys Res Lett. 2012;39, L17807. doi:10.1029/ 2012GL052432.

38. Jaffe DA, Wigder N, Downey N, Pfister G, Boynard A, Reid SB. Impact of wildfires on ozone exceptional events in the Western, US. Environ Sci Tech. 2013;47:11065-72. doi:10.1021/ es402164f.

39. Singh HB, Cai C, Kaduwela A, Weinheimer A, Wisthaler A. Interactions of fire emissions and urban pollution over California: ozone formation and air quality simulations. Atmos Environ. 2012;56:45-51. doi:10.1016/j.atmosenv.2012.03.046.

40. Wigder NL, Jaffe DA, Saketa FA. Ozone and particulate matter enhancements from regional wildfires observed at Mount Bachelor during 2004-2011. Atmos Environ. 2013;75:24-31. doi:10.1016/j.atmosenv.2013.04.026.

41. Hodnebrog Ø, Solberg S, Stordal F, Svendby TM, Simpson D, Gauss M, et al. Impact of forest fires, biogenic emissions and high temperatures on the elevated Eastern Mediterranean ozone levels during the hot summer of 2007. Atmos Chem Phys. 2012;12: 8727-50. doi:10.5194/acp-12-8727-2012.

42. Martins V, Miranda AI, Carvalho A, Schaap M, Borrego C, Sa E. Impact of forest fires on particulate matter and ozone levels during the 2003, 2004 and 2005 fire seasons in Portugal. Sci Total Environ. 2012;414:53-62. doi:10.1016/j.scitotenv.2011.10.007.

43. Putero D, Landi TC, Cristofanelli P, Marinoni A, Laj P, Duchi R, et al. Influence of open vegetation fires on black carbon and ozone variability in the southern Himalayas (NCO-P, 5079 m a.s.1.). Environ Pollut. 2014;184:597-604.

44. Lin YC, Lin CY, Lin PH, Engling G, Lin YC, Lan YY, et al. Influence of Southeast Asian biomass burning on ozone and carbon monoxide over subtropical Taiwan. Atmos Environ. 2013;64: 358-65. doi:10.1016/j.atmosenv.2012.09.050.

45. Toh YY, Lim SF, von Glasow R. The influence of meteorological factors and biomass burning on surface ozone concentrations at Tanah Rata, Malaysia. Atmos Environ. 2013;70:435-46. doi:10.1016/j.atmosenv.2013.01.018.

46. Bousquet P, Ciais P, Miller JB, Dlugokencky EJ, Hauglustaine DA, Prigent C, et al. Contribution of anthropogenic and natural sources to atmospheric methane variability. Nature. 2006;443: 439-43. doi:10.1038/nature05132.

47. Kirschke S, Bousquet P, Ciais P, Saunois M, Canadell JG, Dlugokencky EJ, et al. Three decades of global methane sources and sinks. Nat Geosci. 2013;6:813-23. doi:10.1038/ngeo1955.

48. Jacobson MZ. Effects of biomass burning on climate, accounting for heat and moisture fluxes, black and brown carbon, and cloud absorption effects. J Geophys Res. 2014;119(14):8980-9002. doi: 10.1002/2014JD021861.

49. Ji Y, Stocker E. Seasonal, intraseasonal, and interannual variability of global land fires and their effects on atmospheric aerosol distribution. J Geophys Res. 2002;107(D23):4697. doi:10.1029/ 2002JD002331.

50. Brito J, Rizzo LV, Morgan WT, Coe H, Johnson B, Haywood J, et al. Ground-based aerosol characterization during the South American Biomass Burning Analysis (SAMBBA) field experiment. Atmos Chem Phys. 2014;14:12069-83. doi:10.5194/acp14-12069-2014.

51. Artaxo P, Rizzo LV, Brito JF, Barbosa HMJ, Arana A, Sena ET, et al. Atmospheric aerosols in Amazonia and land use change: from natural biogenic to biomass burning conditions. Faraday Discuss. 2013;165:203-35. doi:10.1039/C3FD00052D. 
52. Lin NH, Tsay S-C, Maring HB, Yen M-C, Sheu G-R, Wang S-H, et al. An overview of regional experiments on biomass burning aerosols and related pollutants in Southeast Asia: from BASEASIA and the Dongsha Experiment to 7-SEAS. Atmos Environ. 2013;78:1-19. doi:10.1016/j.atmosenv.2013.04.066.

53. Zauscher MD, Wang Y, Moore MJK, Gaston CJ, Prather KA. Air quality impact and physicochemical aging of biomass burning aerosols during the 2007 San Diego Wildfires. Environ Sci Technol. 2013;47:7633-43. doi:10.1021/es4004137.

54. Gibson MD, Haelssig J, Pierce JR, Parrington M, Franklin JE, Hopper JT, et al. A comparison of four receptor models used to quantify the boreal wildfire smoke contribution to surface PM2.5 in Halifax, Nova Scotia during the BORTAS-B experiment. Atmos Chem Phys. 2015;15:815-27. doi:10.5194/ acp-15-815-2015.

55. Spracklen DV, Logan JA, Mickley LJ, Park RJ, Yevich R, Westerling AL, et al. Wildfires drive interannual variability of organic carbon aerosol in the western U.S. in summer. Geophys Res Lett. 2007;34:L16816. doi:10.1029/2007GL030037.

56. Yue X, Mickley LJ, Logan JA, Kaplan JO. Ensemble projections of wildfire activity and carbonaceous aerosol concentrations over the western United States in the mid-21st century. Atmos Environ. 2013;77:767-80.

57. Bougiatioti A, Stavroulas I, Kostenidou E, Zarmpas P, Theodosi $\mathrm{C}$, Kouvarakis G, et al. Processing of biomass-burning aerosol in the eastern Mediterranean during summertime. Atmos Chem Phys. 2014;14:4793-807. doi:10.5194/acp-14-4793-2014.

58. Diapouli E, Popovicheva O, Kistler M, Vratolis S, Persiantseva N, Timofeev M, et al. Physicochemical characterization of aged biomass burning aerosol after long-range transport to Greece from large scale wildfires in Russia and surrounding regions, Summer 2010. Atmos Environ. 2014;96:393-404. doi:10.1016/j.atmosenv. 2014.07.055.

59. Reche C, Viana M, Amato F, Alastuey A, Moreno T, Hillamo R, et al. Biomass burning contributions to urban aerosols in a coastal Mediterranean City. Sci Total Environ. 2012;427-428:175-90. doi:10.1016/j.scitotenv.2012.04.012.

60. Portin H, Mielonen T, Leskinen A, Arola A, Parjala E, Romakkaniemi S, et al. Biomass burning aerosols observed in Eastern Finland during the Russian wildfires in summer 2010 Part 1: in-situ aerosol characterization. Atmos Environ. 2012;47: 269-78. doi:10.1016/j.atmosenv.2011.10.067.

61. Corrigan AL, Russell LM, Takahama S, Äijälä M, Ehn M, Junninen $\mathrm{H}$, et al. Biogenic and biomass burning organic aerosol in a boreal forest at Hyytiälä, Finland, during HUMPPA-COPEC 2010. Atmos Chem Phys. 2013;13:12233-56. doi:10.5194/acp13-12233-2013.

62. Shindell DT, Chin M, Dentener F, Doherty RM, Faluvegi G, Fiore AM, et al. A multi-model assessment of pollution transport to the Arctic. Atmos Chem Phys. 2008;8:5353-72. doi:10.5194/acp-85353-2008

63. Warneke C, Froyd KD, Brioude J, Bahreini R, Brock CA, Cozic J, et al. An important contribution to springtime Arctic aerosol from biomass burning in Russia. Geophys Res Lett. 2010;37, L01801. doi:10.1029/2009GL041816.

64. Reisen F, Meyer CP, Keywood MD. Impact of biomass burning sources on seasonal aerosol air quality. Atmos Environ. 2013;67: 437-47. doi:10.1016/j.atmosenv.2012.11.004.

65. Fromm M, Lindsey DT, Servranckx R, Yue G, Trickl T, Sica R, et al. The untold story of Pyrocumulonimbus. Bull Am Meteorol Soc. 2010;91(9):1193-209. doi:10.1175/2010bams3004.1.

66. Livesey NJ, Logan JA, Santee ML, Waters JW, Doherty RM, Read WG, et al. Interrelated variations of O-3, CO and deep convection in the tropical/subtropical upper troposphere observed by the Aura Microwave Limb Sounder (MLS) during 2004-2011.
Atmos Chem Phys. 2013;13(2):579-98. doi:10.5194/acp-13579-2013.

67. Sofiev M, Vankevich R, Ermakova T, Hakkarainen J. Global mapping of maximum emission heights and resulting vertical profiles of wildfire emissions. Atmos Chem Phys. 2013;13(14):7039-52. doi:10.5194/acp-13-7039-2013.

68. Peterson D, Hyer E, Wang J. Quantifying the potential for highaltitude smoke injection in the North American boreal forest using the standard MODIS fire products and subpixel-based methods. J Geophys Res. 2014;119(6):3401-19. doi:10.1002/2013jd021067.

69. Pumphrey HC, Santee ML, Livesey NJ, Schwartz MJ, Read WG. Microwave Limb Sounder observations of biomassburning products from the Australian bush fires of February 2009. Atmos Chem Phys. 2011;11(13):6285-96. doi:10.5194/ acp-11-6285-2011.

70. Siddaway JM, Petelina SV. Transport and evolution of the 2009 Australian Black Saturday bushfire smoke in the lower stratosphere observed by OSIRIS on Odin. J Geophys Res. 2011;116. doi:10.1029/2010jd015162.

71. Glatthor N, Höpfner M, Semeniuk K, Lupu A, Palmer PI, McConnell JC, et al. The Australian bushfires of February 2009: MIPAS observations and GEM-AQ model results. Atmos Chem Phys. 2013;13(3):1637-58. doi:10.5194/acp-13-1637-2013.

72. Vernier JP, Pommereau JP, Thomason LW, Pelon J, Garnier A, Deshler T, et al. Overshooting of clean tropospheric air in the tropical lower stratosphere as seen by the CALIPSO lidar. Atmos Chem Phys. 2011;11(18):9683-96. doi:10.5194/acp-119683-2011.

73. Trickl T, Giehl H, Jaeger H, Vogelmann H. 35 yr of stratospheric aerosol measurements at Garmisch-Partenkirchen: from Fuego to Eyjafjallajokull, and beyond. Atmos Chem Phys. 2013;13(10): 5205-25. doi:10.5194/acp-13-5205-2013.

74. Myhre G, Shindell D, Bréon F-M, Collins W, Fuglestvedt J, Huang $\mathrm{J}$, et al. Anthropogenic and natural radiative forcing. In: Stocker TF, Qin D, Plattner G-K, Tignor M, Allen SK, Boschung J, Nauels A, Xia Y, Bex V, Midgley PM, editors. Climate Change 2013: the physical science basis. Contribution of working group I to the fifth assessment report of the Intergovernmental Panel on Climate Change. Cambridge: Cambridge University Press; 2013.

75. Isaksen ISA, Granier C, Myhre G, Berntsen TK, Dalsoren SB, Gauss M, et al. Atmospheric composition change: climatechemistry interactions. Atmos Environ. 2009;43:5138-92. doi: 10.1016/j.atmosenv.2009.08.003.

76. Chubarova N, Nezval' Y, Sviridenkov M, Smirnov A, Slutsker I. Smoke aerosol and its radiative effects during extreme fire event over Central Russia in summer 2010. Atmos Meas Tech Discuss. 2011;4:6351-86. doi:10.5194/amtd-4-6351-2011.

77. Natarajan M, Pierce RB, Schaack TK, Lenzen AJ, Al-Saadi JA, Soja AJ, et al. Radiative forcing due to enhancements in tropospheric ozone and carbonaceous aerosols caused by Asian fires during spring 2008. J Geophys Res. 2012;117, D06307. doi:10. 1029/2011JD016584.

78. Sena ET, Artaxo P, Correia AL. Spatial variability of the direct radiative forcing of biomass burning aerosols and the effects of land use change in Amazonia. Atmos Chem Phys. 2013;13:126175. doi:10.5194/acp-13-1261-2013.

79. Koren I, Martins JV, Remer LA, Afargan H. Smoke invigoration versus inhibition of clouds over the amazon. Science. 2008;321: 946-9. doi:10.5194/acp-14-9641-2014.

80. Tosca MG, Diner DJ, Garay MJ, Kalashnikova OV. Observational evidence of fire-driven reduction of cloud fraction in tropical Africa. J Geophys Res. 2014; 119(13), doi: 10.1002/2014JD021759.

81. Ten Hoeve JE, Jacobson MZ, Remer LA. Comparing results from a physical model with satellite and in situ observations to determine whether biomass burning aerosols over the Amazon brighten 
or burn off clouds. J Geophys Res. 2012;117(D8):8203. doi:10. 1029/2011JD016856.

82. Lee SS, Feingold G, McComiskey A, Yamaguchi T, Koren I, Martins JV, et al. Effect of gradients in biomass burning aerosol on shallow cumulus convective circulations. J Geophys Res. 2014;119(16):9948-64. doi:10.1002/2014JD021819.

83. Zhang Y, Fu R, Yu H, Qian Y, Dickinson R, Silva Dias MAF, et al. Impact of biomass burning aerosol on the monsoon circulation transition over Amazonia. Geophys Res Lett. 2009;36, L10814. doi:10.1029/2009GL037180.

84. Ward DS, Kloster S, Mahowald NM, Rogers BM, Randerson JT, Hess PG. The changing radiative forcing of fires: global model estimates for past, present and future. Atmos Chem Phys. 2012;12: 10857-86. doi:10.5194/acp-12-10857-2012. The first study to estimate the preindustrial to present-day to future radiative forcing resulting from fires, examining a range of possible impacts.

85. Spracklen DV, Rap A. Natural aerosol-climate feedbacks suppressed by anthropogenic aerosol. Geophys Res Lett. 2013;40: 5316-9. doi:10.1002/2013GL057966.

86. Tosca MG, Randerson JT, Zender CS. Global impact of smoke aerosols from landscape fires on climate and the Hadley circulation. Atmos Chem Phys. 2013;13:5227-41. doi:10.5194/acp-135227-2013.

87. Paton-Walsh C, Emmons LK, Wiedinmyer C. Australia's Black Saturday fires - comparison of techniques for estimating emissions from vegetation fires. Atmos Environ. 2012;60:262-70. doi:10.1016/j.atmosenv.2012.06.066.

88. Zhang X, Kondragunta S, Roy DP. Interannual variation in biomass burning and fire seasonality derived from geostationary satellite data across the contiguous United States from 1995 to 2011. J Geophys Res. 2014;119(6):1147-62. doi:10.1002/ 2013jg002518.

89. Krol M et al. How much $\mathrm{CO}$ was emitted by the 2010 fires around Moscow? Atmos Chem Phys. 2013;13(9):4737-47. doi:10.5194/ acp-13-4737-2013.

90. Zhang F, et al. Sensitivity of mesoscale modeling of smoke direct radiative effect to the emission inventory: a case study in northern sub-Saharan African region. Environ Res Lett. 2014;9(7). doi:10. 1088/1748-9326/9/7/075002.

91. Remy S, Kaiser JW. Daily global fire radiative power fields estimation from one or two MODIS instruments. Atmos Chem Phys. 2014;14:13377-90. doi:10.5194/acp-14-13377-2014.

92. Zhang X, Kondragunta S, Ram J, Schmidt C, Huang H-C. Nearreal-time global biomass burning emissions product from geostationary satellite constellation. J Geophys Res. 2012;117, D14. doi: 10.1029/2012jd017459.

93. Roberts G, Wooster MJ, Freeborn PH, Xu W. Integration of geostationary FRP and polar-orbiter burned area datasets for an enhanced biomass burning inventory. Remote Sens Environ. 2011;115(8):2047-61. doi:10.1016/j.rse.2011.04.006.

94. Schroeder W, Oliva P, Giglio L, Csiszar IA. The new VIIRS $375 \mathrm{~m}$ active fire detection data product: algorithm description and initial assessment. Remote Sens Environ. 2014;143:85-96. doi:10.1016/ j.rse.2013.12.008.

95. Wooster MJ, Xu W, Nightingale T. Sentinel-3 SLSTR active fire detection and FRP product: pre-launch algorithm development and performance evaluation using MODIS and ASTER datasets. Remote Sens Environ. 2012;120:236-54. doi:10.1016/j.rse.2011. 09.033 .

96. Wooster MJ, Perry GLW, Zoumas A. Fire, drought and El Nino relationships on Borneo (Southeast Asia) in the pre-MODIS era (1980-2000). Biogeosciences. 2012;9(1):317-40. doi:10.5194/ bg-9-317-2012.

97. Mu M et al. Daily and 3-hourly variability in global fire emissions and consequences for atmospheric model predictions of carbon monoxide. J Geophys Res. 2011;116, D24303. doi:10.1029/ $2011 \mathrm{jd} 016245$.

98. Freeborn PH, Wooster MJ, Roy DP, Cochrane MA. Quantification of MODIS fire radiative power (FRP) measurement uncertainty for use in satellite-based active fire characterization and biomass burning estimation. Geophys Res Lett. 2014;41(6):1988-94. doi: 10.1002/2013g1059086.

99. van Leeuwen TT et al. Biomass burning fuel consumption rates: a field measurement database. Biogeosciences. 2014;11(24):7305-29.

100. van Leeuwen TT, Peters W, Krol MC, van der Werf GR. Dynamic biomass burning emission factors and their impact on atmospheric CO mixing ratios. J Geophys Res. 2013;118(12):6797-815. doi: 10.1002/jgrd.50478.

101. Val Martin M, Kahn RA, Logan JA, Paugam R, Wooster M, Ichoku C. Space-based observational constraints for 1-D fire smoke plume-rise models. J Geophys Res. 2012;117, D22204. doi:10.1029/2012jd018370.

102. Arora VK, Boer GJ. Fire as an interactive component of dynamic vegetation models. J Geophys Res. 2005;110, G02008. doi:10. 1029/2005JG000042.

103. Thonicke K, Spessa A, Prentice IC, Harrison SP, Dong L, Carmona-Moreno C. The influence of vegetation, fire spread and fire behaviour on biomass burning and trace gas emissions: results from a process-based model. Biogeosciences. 2010;7: 1991-2011. doi:10.5194/bg-7-1991-2010.

104. Coen JL, Cameron M, Michalakes J, Patton EG, Riggan PJ, Yedinak KM. WRF-fire: coupled weather-wildland fire modeling with the weather research and forecasting model. J Appl Meteorol. 2013;52(1):16-38. doi:10.1175/jamc-d-12-023.1.

105. Khairoutdinov MF, Randall DA, DeMotte C. Simulations of the atmospheric general circulation using a cloud-resolving model as a super-parameterization of physical processes. J Atmos Sci. 2005;62:2136-54.

106. Anenberg SC, Schwartz J, Shindell D, Amann M, Faluvegi G, Klimont Z, et al. Global air quality and health co-benefits of mitigating near-term climate change through methane and black carbon emission controls. Environ Health Perspect. 2012;120:831-9.

107. Marlier ME, DeFries RS, Voulgarakis A, Kinney PL, Randerson JT, Shindell DT, et al. El Niño and health risks from landscape fire emissions in southeast Asia. Nat Clim Chang. 2013;3:131-6. doi: 10.1038/nclimate1658.

108. Johnston FH, Henderson SB, Chen Y, Randerson JT, Marlier M, DeFries RS, et al. Estimated global mortality attributable to smoke from landscape fires. Environ Health Perspect. 2012;120:695701. doi:10.1289/ehp. 1104422.

109. Kinney PL. Climate change, air quality, and human health. Am J Prev Med. 2008;35:459-67. doi:10.1016/j.amepre.2008.08.025. 